Article

\title{
Characteristics and Rates of Microbial Processes in Clays of Different Mineral and Elemental Composition in Relation to Safety Prediction for ESB Clay Materials
}

\author{
Elena Abramova, Nadezhda Popova (D), Grigoriy Artemiev, Viktoria Zharkova, Elena Zakharova \\ and Alexey Safonov*(D)
}

Citation: Abramova, E.; Popova, N.; Artemiev, G.; Zharkova, V.;

Zakharova, E.; Safonov, A.

Characteristics and Rates of Microbial Processes in Clays of Different Mineral and Elemental Composition in Relation to Safety Prediction for ESB Clay Materials. Appl. Sci. 2022, 12, 1843. https:// doi.org/10.3390/app12041843

Academic Editors: Muhammad Junaid Munir and Fernando Rocha

Received: 30 November 2021

Accepted: 7 February 2022

Published: 10 February 2022

Publisher's Note: MDPI stays neutral with regard to jurisdictional claims in published maps and institutional affiliations.

Copyright: (C) 2022 by the authors. Licensee MDPI, Basel, Switzerland. This article is an open access article distributed under the terms and conditions of the Creative Commons Attribution (CC BY) license (https:// creativecommons.org/licenses/by/ $4.0 /$ )
Frumkin Institute of Physical Chemistry, Russian Academy of Science, 119071 Moscow, Russia; gorchicta246@mail.ru (E.A.); no.hope996@gmail.com (N.P.); artemyev56@gmail.com (G.A.); v.zarkova11@gmail.com (V.Z.); v.m.ermolaev@gmail.com (E.Z.)

* Correspondence: alexeysafonof@gmail.com

\begin{abstract}
Microbial activity in clay barrier materials during radioactive waste disposal can lead to a violation of important physicochemical properties of the barrier system as a whole, thereby reducing the safety of the storage facility. This work evaluates the activity of the microbial complex of five bentonite and two kaolin clays. All clay materials were found to contain microorganisms, mostly with organotrophic aerobic and anaerobic metabolism capable of forming hydrogen sulfide and transforming basic and impurity clay minerals. The activity of microorganisms can increase with the ingress of degradation products of aluminophosphate matrices and cement barriers, as well as radiolysis products. For all clay the rates of microbial processes were shown to exhibit a direct correlation with the content of organic matter, kaolinite, and potassium feldspar, and an inverse correlation with montmorillonite content. A systematic methodological approach is proposed for clay materials and their susceptibility to microbial processes. The approach makes it possible, based on the content of organic matter, biophilic elements in the samples, parameters of the respiratory activity of the microbial complex, the formation of hydrogen sulfide, and other parameters, to assess in advance the possibility of using them in barriers.
\end{abstract}

Keywords: clay-based engineered barriers; clay materials; kaolinite; bentonite; microbial respiration; microbial clay dissolution; $\mathrm{H}_{2} \mathrm{~S}$ production; correlation analysis

\section{Introduction}

Due to their antifiltration properties, clay-based engineered safety barriers (ESB) are used for conservation of radiation-hazardous objects, including on-the-spot disposal [1]; as a matrix material for radioactive waste (RW) conditioning [2]; and at the sites of subsurface and deep geological RW disposal (DGR). Clays and clay materials are used for deep disposal of the waste of nuclear power plants in the USA, France, Sweden, etc. [3-6]; it is also planned in Russia [7,8].

The main characteristics of clay materials and of the barriers based on these materials, which provide for long-term storage safety are low filtration and diffusion coefficients, high coefficients of radionuclide interfacial distribution, high specific surface, significant swelling pressure, etc. [9]. Bentonite clays with high montmorillonite content are therefore the most promising ESB components. Polymineral materials with kaolin clay nowadays are used in barriers for nuclear legacy objects conservation [10]. The advantages of kaolin clays include their uniform fractional composition and resistance to physicochemical effects of high temperature and aggressive environments [11].

The long-term evolution of clay materials in DGR depends on a number of physicochemical factors, including the coevolution of other barriers in the system (steel or copper 
metal containers, cement materials, etc.) $[12,13]$. Among the factors affecting clay properties during long-term DGR storage is the biological one [3]. Microbial processes may affect both the mineral composition and the properties of clay materials, especially their filtration and sorption properties. Microorganisms may promote phyllosilicate dissolution both directly by extraction of the mineral-forming elements by biofilms (for example by secretion of siderophores binding to $\mathrm{Fe}$ and $\mathrm{Al}$ ), and indirectly, e.g., by acidification or alkalization [14-17] of the medium. The main process initiating microbial transformations of clay minerals is the reductive leaching of iron, leading to a change in the layer charge. Smectization proceeds through a process of depletion and exchange of interlayer $\mathrm{K}$ and concomitant decrease of layer charge. Illitization is smectite transformation to illite by increased layer charge and by potassium or ammonium fixation in the interlayer. Illitization can be accompanied by a microbial iron reduction in former smectite [18-20].

Microbiological investigation constitutes a significant part of the research programs of RW disposal sites worldwide. Clays microbial diversity study in the Boom underground research laboratory (URL) HADES [21] revealed the community with the predominance of organotrophic members of the phyla Proteobacteria, Actinobacteria, Bacteroidetes, and Firmicutes, as well as aerobic and anaerobic bacteria capable of sulfate and iron reduction (genera Acidithiobasillus, Desulfovibrio, and Desulfomaculum). Since sulfide production enhances steel corrosion, it is considered one of the most negative biogeochemical factors in DGR.

Investigation of Opalinus clays at Mont-Terri Rock Laboratory (Switzerland) [6] revealed bacteria of the genera Pseudomonas, Pleomorphomonas, Desulfosporosinus, and Desulfocapsa, capable of sulfate and iron reduction, including the autotrophic processes with $\mathrm{H}_{2}$ and $\mathrm{CO}_{2}$ as an electron donor and carbon source, respectively.

Activation of microbial processes by biophilic elements and organic matter of clays, as well as by external electron donors, such as molecular hydrogen produced by radiolysis or steel corrosion [21,22], may affect the evolution of other safety barriers, causing, for example, corrosion of metal containers or promoting cement degradation [23].

Using compacted bentonite with a density above $1.5 \mathrm{~g} / \mathrm{cm}^{3}$ is one of the ways to suppress microbial activity [24]. However, some works report microbial activity both on the surface of compressed bentonite and in the system of compacted bentonite with the density of 1.75 and $2 \mathrm{~g} / \mathrm{cm}^{3}$, where sulfide formation indicates the activity of sulfate-reducing bacteria (SRB) was detected $[25,26]$. As an alternative to compaction, biocidal additives may be supplemented to the engineering mixtures, e.g., ammonium salt of O,O-dialkyl dithiohosphoric acid [27], polyhexamethyl guanidine [28-30], derivatives of isothiazole and brominated nitropropane dioles [31], or Amanat, Rancid, and boric acid [32].

Thus, since the rates of microbial processes in clay materials may play an important part in the evolution of the whole system of engineered safety barriers, the goal of the present work was to select the approaches to determine the safety of clay application in ESB using seven different clay types. Mineral and elemental composition of the samples, the composition of their microbial complexes, and assessment of the rates and directions of microbial processes under model conditions were chosen as the main criteria.

\section{Materials and Methods}

Five bentonite and two kaolin materials used in the work are listed in Table 1.

The clays of the Zyryanskoye, Kampanovsk and Kantatsk deposits are of sedimentary origin, from Kamalinsk and 10th Khutor are volcanogenic-sedimentary [8,35]. Tagansk and Kutch deposits are residual, hydrothermal origin [36].

In this study, clay powders, dried and crushed in industrial installations were used. All materials were obtained from non-activated raw materials. The cured clay (after natural drying) was preliminarily crushed in a disintegrator, then fed into a drying drum, where it was dried at a temperature of no more than $200{ }^{\circ} \mathrm{C}$. After the drum, the clay raw material entered the pendulum mill. The maximum particle size of the obtained clay powder did 
not exceed 1000 microns. The moisture content of the finished product depended on the type of clay: for bentonites- $8-10 \%$, for kaolins $-2-5 \%$.

Table 1. Description of the clay materials.

\begin{tabular}{ccc}
\hline Clay Type & Designation & Sample \\
\hline Bentonite & B-1 & Kutch deposit (India) [33] \\
& B-2 & Tagansk deposit, Dinozavrov (Kazakhstan) [34] \\
& B-3 & Ceraceous bentonite, Kamalinsk deposit (Krasnoyarsk region, Russia) [10] \\
& B-4 & 10th Khutor deposit (Khakassiya, Russia) \\
Kaolin & K-5 & Zyryanskoye deposit of bentonite (Kurgan oblast, Russia) [10] \\
& K-2 & Kantatsk deposit (Krasnoyarsk region, Russia) [10] \\
& & Kampanovsk deposit (Krasnoyarsk region, Russia) [11] \\
\hline
\end{tabular}

\subsection{Model Experiments}

A detailed description of the experiments is given in Table S1 (Supplementary Information).

For the availability of water-soluble complex study, suspended clay samples $(1 \mathrm{~g})$ were sustained in penicillin vials with distilled water for 30 days. Aqueous phase samples were taken for element measure once at the end of the experiment. At the second stage, the acid-soluble bioavailable fraction was assessed by treating $1 \mathrm{~g}$ of the sample with a $0.1 \mathrm{M}$ hydrochloric acid solution.

For the clay microbial complex activity study, suspended clay samples $(1 \mathrm{~g})$ in penicillin vials were incubated in $10 \mathrm{~mL}$ of low-mineral liquid medium simulating the groundwater composition at the Yeniseisky site where a DGR storage facility is planned [37,38]. The medium composition was (mg/L): $\mathrm{NaHCO}_{3}, 272 ; \mathrm{CaCl}_{2}, 71.8 ; \mathrm{MgSO}_{4} * 7 \mathrm{H}_{2} \mathrm{O}, 70 ; \mathrm{pH} 7.0$; $\mathrm{t}=20^{\circ} \mathrm{C}$. A mixture of sodium acetate, 1000 and glucose, 1000 was used as a carbon source for microbial stimulation. The incubation duration was 15 days. In this series of experiments, the microbial respiratory activity of the sample was measured and a single sampling of the liquid phase was carried out for the element content analysis. The same clay samples irradiated for $10 \mathrm{~min}$ with an ultraviolet lamp $\left(\lambda=253.7 \mathrm{~nm}, 15 \mathrm{~mW} / \mathrm{cm}^{2} / \mathrm{s}\right)$ served as a control. No organic matter was added to the control sample.

In this series of experiments, the effect of additives on the respiratory activity of the microbial complex was measured and the formation of hydrogen sulfide, the most aggressive cellular metabolite capable of corroding steel, was assessed.

\subsection{Procedures}

For DNA isolation from clays, the sample $(2 \mathrm{~g})$ was dispersed in $10 \mathrm{~mL}$ of Tris-EDTA buffer. DNA was isolated using the specialized DNeasy PowerSoil HTP 96 Kit (384) (Qiagen, Venlo, The Netherlands) the specialized kit for DNA isolation from soils, according to the manufacturer's recommendations. In preparing libraries for amplification, variable parts of a gene of the V3-V4 region of 16S rRNA were selected: for amplification of the V3V4 region, the degenerate primers For341 (5'-CCTACGGGNBGCASCAG-3") and Rev806 (5"-GGACTACHVGGGTWTCTAAT-3") were used. For amplification of the V4 region, the degenerate primers For515 (5"-GTGBCAGCMGCCGCGGTAA-3") and Rev806 (5"GGACTACHVGGGTWTCTAAT-3") were used. Amplification was performed by real-time PCR on a CFX96 Touch (Bio-Rad, Hercules, CA, USA) device using qPCRmix-HS SYBR (Eurogen, Moscow, Russia).

Denaturation, primer annealing, and chain elongation for the V3-V4 region were carried out at temperatures of 96,54 , and $72{ }^{\circ} \mathrm{C}$, respectively, and steps for the $\mathrm{V} 4$ region were carried out at temperatures of 96,58 , and $72^{\circ} \mathrm{C}$, respectively. Purification of the desired product from each batch was conducted with Agencourt AMPure XP (Beckman Coulter, Brea, CA, USA) magnetic particles. Furthermore, high-throughput sequencing was performed via the MiSeq system (Illumina, San Diego, CA, USA) using a reagent kit (MiSeq Kit v2, 500 cycles, Illumina, USA). 
Respiratory activity was determined using the MTT test [39] under oxic and anoxic conditions. Before spectrophotometry of the oxidized formazan complex, the samples were centrifuged at $7000 \mathrm{~g}$ to remove the clay suspension. The coefficients of the respiratory activity increase were calculated as the ratio of activity on day 15 to the initial value for oxic ( $\left.\mathrm{K}_{\text {MTTox }}\right)$ and anoxic conditions (K $\left.\mathrm{K}_{\text {MTTanox }}\right)$.

Concentrations of elements in the solution were determined by mass spectrometry with inductively bound plasma on Element-2 (Thermo Scientific, Waltham, MA, USA). The samples were filtered through a $0.22 \mathrm{~nm}$ filter, acidified with nitric acid to $\mathrm{pH} 1$.

Biological leaching was calculated as the ratio of ion concentrations in the experiment to the value for the control (sample treated by UV and without organic substance). Concentrations of elements were measured by ICP-MS.

Sulfide concentration was determined calorimetrically with dimethyl-p-phenylenediamine according to the modified method of [40].

The mineral composition of the clay samples was determined on a -Xray diffractometer "X'pert PRO MPD" manufactured by PANalytical (Almelo, The Netherlands) with Cu K $\alpha$ anode at $50 \mathrm{kV}$ and $40 \mathrm{~mA}$ in continuous mode of recording X-ray patterns, (step $0.02 \mathrm{deg}$ $2 \theta$, pulse acquisition time $1 \mathrm{~s}$ ) at the mineralogical department of the FSBI VIMS. Detection limits depend on crystallinity but were typically $0.1-1 \mathrm{wt} \%$. In general, the crystallinity of the measured samples was quite high. Interpretation of results was carried out using internal standards according to the methodology of the FSBI VIMS.

Concentrations of the major and extrinsic elements in the samples were determined by X-ray spectral fluorescence analysis on Axios mAX Advanced sequential vacuum spectrometer (with dispersion by the wavelength) (PANalytical, Almelo, The Netherlands). Standard samples of the US Geological Survey (USGS) were used as the controls.

Organic carbon was determined by the total organic carbon analyzer Shimadzu TOC-V CSN (Kyoto, Japan). Before TOC analysis, carbonates were removed from the samples by treatment with $0.02 \mathrm{~N} \mathrm{HCl}$ during the day with periodic agitation until a constant acidic reaction of the medium.

Correlation analysis was carried out using the Past 4.03 software package. A quantitative assessment of relations between biological processes and elemental composition of the minerals was carried out using the Spearman rank correlation coefficient, an indicator of the degree of relationship. Quantitative assessment was carried out according to the Chaddock scale. The materials were grouped according to their biological activity using the scale of 1 to 5 , constructing histograms of the intervals for each parameter.

\section{Results}

\subsection{Mineral and Elemental Composition of the Samples}

The occurrence of microbial processes in the samples requires biophilic elements, especially sulfur, phosphorus, carbon, and nitrogen.

All elements required for cell growth were present in samples B-4, B-5, and K-1 (Table 2), with the highest levels of carbon and nitrogen found in the bentonite clay B-5 and kaolin clay K-1. The sample B5 had also the highest content of phosphorus and sulfur. In the samples B-1 and B-2, concentrations of nitrogen and phosphorus were below the detection limit. Iron was present in all samples, with its highest content in sample B-1.

Table 2. Elements content in clay samples, mass \%.

\begin{tabular}{|c|c|c|c|c|c|c|c|c|c|c|}
\hline Sample & $\mathbf{K}$ & $\mathrm{Na}$ & $\mathrm{Ca}$ & $\mathrm{Mg}$ & $\mathrm{Fe}$ & $\mathrm{S}$ & $\mathrm{C}^{*}$ & $\mathbf{N}$ & $\mathbf{P}$ & $\mathrm{C} / \mathrm{N}$ \\
\hline B-1 & 0.06 & 1.40 & 1.50 & 2.87 & 14.0 & 0.05 & 0.19 & 0 & 0 & 0 \\
\hline B-2 & 0.05 & 1.07 & 1.45 & 3.33 & 3.2 & 0.05 & 0.14 & 0 & 0 & 0 \\
\hline B-3 & 1.08 & 0.1 & 1.68 & 3.42 & 3.4 & $<0.02$ & 0.01 & 0 & 0.05 & 0 \\
\hline B-4 & 0.71 & 0.91 & 2.05 & 2.73 & 2.4 & 0.04 & 0.34 & 0.01 & 0.1 & 34.2 \\
\hline B-5 & 0.78 & 0.57 & 3.93 & 1.73 & 4.2 & 0.08 & 0.86 & 0.03 & 0.2 & 25.2 \\
\hline K-1 & 1.01 & 0.68 & 1.54 & 2.87 & 3.4 & $<0.02$ & 0.41 & 0.03 & 0.1 & 13.7 \\
\hline $\mathrm{K}-2$ & 1.3 & 0.03 & 0.30 & 0.53 & 1.6 & $<0.02$ & 0.11 & 0 & 0 & 0 \\
\hline
\end{tabular}

* Organic carbon, measured by TOC analysis with $\mathrm{HCl}$ pretreatment. 
All studied samples contained montmorillonite; most of them contained also kaolinite (Table 3).

Table 3. Mineral composition of the clay materials.

\begin{tabular}{|c|c|c|c|c|c|c|c|c|c|c|}
\hline \multirow{2}{*}{ Sample } & \multirow{2}{*}{ Quartz } & \multicolumn{4}{|c|}{ Clay Minerals } & \multirow{2}{*}{$\begin{array}{c}\text { Feldspars } \\
\text { PFS }\end{array}$} & \multicolumn{3}{|c|}{ Other Minerals } & \multirow{2}{*}{ Residual * } \\
\hline & & Kaolinite & Montmorillonite & Illite & Muscovite & & Plagioclases & Calcite & Anatase & \\
\hline B-1 & 4 & - & 78 & - & - & - & - & 1.5 & 1.5 & 15 \\
\hline B-2 & 9 & - & 89.5 & - & - & - & - & 1.5 & - & - \\
\hline B-3 & 27 & 5 & 60 & - & 1 & 6 & - & - & - & 1 \\
\hline B-4 & 11.5 & 4 & 71 & 1 & - & 4 & 5 & 3 & - & 0.5 \\
\hline B-5 & 16 & 6 & 67 & 3 & - & 0.5 & 1.5 & 5 & 1 & - \\
\hline K-1 & 25 & 24 & 15 & 5 & - & 5 & 6 & 1.5 & 1 & 17.5 \\
\hline K-2 & 8.5 & 81 & 2 & 2 & - & 6 & - & - & - & 0.5 \\
\hline
\end{tabular}

* X-ray amorphous phase together with phases, the content of which is below the detection threshold.

In all clay minerals, Fe, $K$, and organic sediments containing $C, N, S$, and $P$ were present as impurities. Sample B-5 had the highest content of organic matter; in sample K-1 its content was considerable compared to the other samples. The presence of potassium in the samples was due to mica and potassium feldspars. The X-ray amorphous phase in sample B-1 was probably associated with high content of iron oxides as mineral forms (e.g., ferrihydrite), which may explain the high iron content in this sample. Iron and potassium are known to play the most important role in microbial clay transformation, since microbial iron reduction initiates the processes resulting in disruption of the crystalline lattice of clay minerals, while potassium is among the most important biophilic elements. Thus, several groups may be identified based on the elemental and mineral composition of the samples: those with high content of organic matter (B-5, K-1), high content of iron (B-1, B-5), and high content of potassium (B-3, K-1, K-2); these samples showed high potential risks of intensification of microbial processes.

\subsection{Biological Availability of Biogenic Elements}

According to the results of leaching experiments with distilled water (Table 4, the highest release of the elements was observed for sample B-2, primarily due to the loss of potassium and sodium. The degree of leaching was higher in the samples B-5 and K-1, compared to the other ones. Loss of potassium, calcium, and magnesium was observed for sample B-5, while sodium and magnesium were predominantly lost from sample K-1. The highest release of iron was observed for samples B-1, B-4, and K-2. Samples B-3 and K-2 exhibited the highest degree of leaching.

Table 4. Heatmap of water soluble (ws) and acid soluble (as) elements fractions in $10 \mathrm{~g}$ of clay samples, $\mathrm{mg} / \mathrm{L}$.

\begin{tabular}{|c|c|c|c|c|c|c|c|c|c|}
\hline Sample & $\mathrm{Na}$ & $\mathbf{K}$ & $\mathrm{Ca}$ & $\mathrm{Mg}$ & $\mathrm{Fe}$ & $\mathrm{S}$ & $\mathbf{P}$ & $\sum$ Leaching & $\mathrm{pH}$ \\
\hline B-1 ws & $8.4 \pm 0.2$ & $1.3 \pm 0.03$ & $5.2 \pm 0.13$ & $11.5 \pm 0.29$ & $2.8 \pm 0.07$ & 1.d.1 & 1.d.1 & 29.2 & 7.8 \\
\hline as & $77 \pm 0.18$ & $3.6 \pm 0.07$ & $105 \pm 2.6$ & $186.55 \pm 4.7$ & $1260 \pm 31.5$ & $0.75 \pm 0.01$ & 1.d.1 & 2007 & - \\
\hline B-2 ws & $26.5 \pm 0.66$ & $1 \pm 0.03$ & $19.5 \pm 0.49$ & $3.1 \pm 0.08$ & $0.1 \pm 0.003$ & 1.d.1 & 1.d.1 & 50.3 & 8.2 \\
\hline as & $58.85 \pm 1.42$ & $3 \pm 0.09$ & $101.5 \pm 2.5$ & $216.45 \pm 5.6$ & $288 \pm 8.64$ & $1.1 \pm 0.03$ & l.d.1 & 910 & - \\
\hline B-3 ws & $5.2 \pm 0.13$ & $2.3 \pm 0.06$ & $6.1 \pm 0.15$ & $2.9 \pm 0.07$ & $0.6 \pm 0.02$ & 1.d.1 & 1.d.1 & 17.2 & 6.3 \\
\hline as & $5.5 \pm 0.13$ & $64.8 \pm 1.7$ & $117.6 \pm 2.9$ & $222.3 \pm 5.3$ & $306 \pm 10.16$ & 1.d.1 & $2.25 \pm 0.05$ & 968 & - \\
\hline B-4 ws & $10.7 \pm 0.27$ & $7.3 \pm 0.18$ & $2.6 \pm 0.07$ & $3.4 \pm 0.09$ & $2.5 \pm 0.06$ & 1.d.1 & 1.d.l & 26.7 & 8.5 \\
\hline as & $50.05 \pm 1.29$ & $42.6 \pm 1.09$ & $143.5 \pm 3.8$ & $177.45 \pm 4.55$ & $213.6 \pm 4.83$ & $0.68 \pm 0.01$ & $4.5 \pm 0.09$ & 880 & - \\
\hline B-5 ws & $11.7 \pm 0.29$ & $2.2 \pm 0.06$ & $13.5 \pm 0.34$ & $5.9 \pm 0.15$ & $0.3 \pm 0.008$ & 1.d.l & l.d.l & 33.6 & 7.4 \\
\hline as & $31.35 \pm 0.8$ & $46.8 \pm 1.29$ & $275.1 \pm 6.89$ & $112.45 \pm 2.8$ & $369.6 \pm 8.79$ & $1.44 \pm 0.04$ & $9 \pm 0.11$ & 1127 & - \\
\hline K-1 ws & $13.2 \pm 0.33$ & $4.3 \pm 0.11$ & $4.8 \pm 0.12$ & $10.9 \pm 0.27$ & $0.2 \pm 0.005$ & 1.d.1 & 1.d.1 & 33.7 & 7.4 \\
\hline as & $37.4 \pm 0.9$ & $60.6 \pm 1.6$ & $107.8 \pm 2.7$ & $186.55 \pm 4.6$ & $265.2 \pm 6.55$ & 1.d.1 & $4.7 \pm 0.09$ & 950 & - \\
\hline K-2 ws & $14 \pm 0.35$ & $1.9 \pm 0.05$ & $3.3 \pm 0.08$ & $2.1 \pm 0.05$ & $2.6 \pm 0.07$ & 1.d.1 & 1.d.1 & 24 & 7.0 \\
\hline as & $16.5 \pm 0.41$ & $61.8 \pm 1.57$ & $21 \pm 0.52$ & $34.45 \pm 0.8$ & $120 \pm 3.15$ & 1.d.1 & l.d.1 & 376 & \\
\hline
\end{tabular}

1.d.l -less detection limits.

Ion release into the solution determines its ionic strength, the factor required for the cells to exist in low-mineral solutions. It is worth adding that in an acidic environment, the leaching of all elements except sulfur (no more than $20 \%$ ) was $40-60 \%$ of the content in the sample, iron up to $90 \%$. Potassium, magnesium, and phosphorus limitation is known to occur in natural groundwater, and the release of these elements may result in a significant increase in the rates of microbial processes. Importantly, samples B-1, B-4, and 
K-2 contained the highest amount of available iron, while samples B-4 and K-1 had the highest amounts of potassium. As was stated above, iron was present in sample B-1 as an amorphous hydroxide, while in samples B-4 and K-1 it most probably occurred in the interlayer spaces of clays, making it more available to microorganisms. However, in the absence of ions capable of replacing the missing element. This process affects the layer charge and therefore results in disruption of the structure lattice [41]. The values of ionic strength after leaching indicate that samples B-1, B-2, B-4, B-5, and K-1 may establish the most favorable conditions for microbial growth in the presence of a liquid medium.

\subsection{Differences in the Composition of the Microbial Complex}

Profiling the clay microbial communities based on the 16S rRNA gene sequences (Table 5) revealed the highest microbial diversity in sample B-3. The predominant organisms in this sample belonged to the genera Massilia (40\%), Noviherbaspirillum (11\%), and Bacillus (14\%). Fermentative bacteria, as well as those reducing sulfate via assimilatory and dissimilatory metabolism are known among the members of these genera. Aerobic and anaerobic oxidation of organic matter in clay barrier materials may result in the production of gases and acidic organic metabolites, disrupting the stability of the steel container and cement barriers.

Table 5. Phylogenetic diversity of microbial communities in clay samples before stimulation.

\begin{tabular}{|c|c|c|c|c|c|c|c|c|c|c|c|c|c|}
\hline B-1 & & B-2 & & B-3 & & B-4 & & B-5 & & K-1 & & K-2 & \\
\hline Lysobacter & 76 & Bacillus & 68 & Massilia & 40 & Bacteroides & 24 & Noviherbaspirillum & 21 & Pseudomonas & 68 & Bacillus & 5 \\
\hline Escherichia- & 3 & Massilia & 18 & Noviherbaspirillum & 11 & Pseudomonas & 4 & Hydrogenophaga & 25 & Bacillus & 16 & Bosea & 6 \\
\hline Ralstonia & 1 & Noviherbaspirillum & 3 & Aquaspirillum & 3 & Acinetobacter & 3 & Brevundimonas & 13 & Unknown & 8 & Cupriavidus & 9 \\
\hline Herbaspirillum & 1 & Aquaspirillum & 1 & Cupriavidus & 1 & Lachnospiraceae & 22 & Caldimonas & 2 & Ralstonia & 2 & Ralstonia & 9 \\
\hline Cupriavidus & 1 & Cupriavidus & 1 & Pseudomonadales & 1 & Ruminococcaceae & 24 & Acidovorax & 2 & Cupriavidus & 1 & Ramlibacter & 5 \\
\hline Aquabacterium & 1 & Pseudomonadales & 1 & Xanthomonadales & 1 & Actinobacteria & 3 & Pelomonas & 3 & Streptococcus & 2 & Gemmatimonas & 1 \\
\hline Sphigomonas & 3 & Acinetobacter & 1 & Methylobacterium & 1 & Hungatella & 3 & Methyloversatilis & 5 & Sphingomonas & 1 & Nocardioides & 12 \\
\hline Devosia & 1 & Psychrobacter & 1 & Afipia & 1 & Brevundimonas & 1 & Thiobacillus & 2 & Rhizobium & 1 & Massilia & 8 \\
\hline Gemmobacter & 1 & Escherichia & 3 & Sphingomonas & 2 & Xanthomonadales & 1 & Xanthomonadales & 4 & Alloprevotella & 1 & Domibacillus & 1 \\
\hline Ensifer & 1 & Klebsiella & 1 & Brevundimonas & 2 & Unknown & 15 & Sphingobium & 3 & & & Pajaroellobacter & 2 \\
\hline Hydrobacter & 1 & Unknown & 2 & Hydrobacter & 8 & & & Rhizobiales & 11 & & & Rhizobium gr. & 20 \\
\hline Ensifer & 1 & & & Corynebacterium & 1 & & & Oleomonas & 2 & & & Rubellimicrobium & 5 \\
\hline Corynebacterium & 2 & & & Actinomyces & 1 & & & Actinobacteria & 1 & & & Unknown & 17 \\
\hline Brachybacterium & 1 & & & Lawsonella & 1 & & & Lachnospiraceae & 1 & & & & \\
\hline Bacillus & 2 & & & Bacillus & 14 & & & Pseudomonas & 1 & & & & \\
\hline Clostridiales & 1 & & & Streptococcus & 3 & & & Unknown & 4 & & & & \\
\hline Actinobacteria & 1 & & & Lactobacillales & 2 & & & & & & & & \\
\hline Unknown & 2 & & & Unknown & 6 & & & & & & & & \\
\hline
\end{tabular}

Predominant organisms in sample B-4 belonged to the genus Bacteroides and the families Lachnospiraceae and Ruminococcaceae. The genus Bacteroides is represented by anaerobic bacteria, mostly with fermentative metabolism [42]. Although bacteria of the families Lachnospiraceae and Ruminococcaceae are predominantly animal symbionts or parasites, many are able to thrive in organic-rich ecosystems, carrying out fermentation or sulfate or iron respiration, depending on the availability of organic matter in the environment [43-46]. The genera Noviherbaspirillum, Hydrogenophaga, Brevundimonas, and order Rhizobiales predominated in sample B-5. Members of the genus Hydrogenophaga are known to ferment organic matter to $\mathrm{H}_{2}$ and organic acids, where some species may use hydrogen as an electron donor (i.e., they may be activated by hydrogen produced by water radiolysis) and ferric iron as an electron acceptor, dissolving iron-containing minerals, including the oxidized corrosion products passivating steel surface [47].

Sample B-1 exhibited a significant predominance of members of the genus Lysobacter, organotrophic bacteria capable of anaerobic growth and iron reduction. Most of the bacteria from sample B-2 belonged to the genera Bacillus and Massilia, which were characterized above.

In sample K-1, the predominant genus was Pseudomonas (68\%), which possesses a broad spectrum of metabolic capabilities, including anaerobic reduction of iron, sulfate, actinides, and technetium [48-50].

Thus, all clay materials were found to contain microorganisms, mostly with organotrophic aerobic and anaerobic metabolism. The samples with the highest diversity were 
B-1, B-3, and B-5. Most of the taxa revealed in clays were not typical of the geosphere but rather belonged to the microorganisms of human habitats. This was probably because prior to their application in barrier materials clays undergo high-temperature treatment (up to $300^{\circ}$ ), primarily for removal of excessive moisture. Clays possess a highly developed surface and may sorb bacteria from the air and various surfaces during subsequent procedures at the plant or during transportation.

\subsection{Respiratory Activity of the Microflora of Clay Samples and Its Stimulation}

In experiments with the low-mineral medium under oxic conditions without stimulation of microbial communities, kaolin clays exhibited the highest values of respiratory activity (Table 6). Bentonite samples B-1 and B-3 exhibited higher respiratory activity than other samples. After stimulation with glucose and acetate (1:1) under oxic conditions for two weeks, the highest respiratory activity (a 25-fold increase) was observed for sample B-5, probably due to its high content of organic matter. Sample B-3 exhibited a significant increase in activity, compared to other samples, where the respiratory activity increased 3to 4 -fold. When the clay microbial complex was activated by adding organic compounds under anoxic conditions, sample B-5 also exhibited the highest increase of its respiratory activity (21.7 times); under these conditions, some samples (e.g., B-1 and B-2) exhibited higher activity when being stimulated under oxic conditions. The respiratory activity of some samples decreased noticeably under these conditions (e.g., B-4, K-1, and K-2). In both cases, the samples B-2, B-4, and K-1 showed the lowest respiratory activity, compared to other samples. Thus, differences in the activity of organotrophic clay microbial communities under oxic and anoxic conditions were revealed. Under DGR conditions, anaerobic organic matter oxidation is more dangerous, since it results in the formation of intermediate oxidation products, including organic acids, which have a negative effect on the integrity of cement and steel materials.

Table 6. Heatmap of the coefficients of increased microbial respiration in clay samples before and after stimulation by acetate and glucose.

\begin{tabular}{cccc}
\hline Sample & MTT $_{\text {init }}$ & KMTTox $_{\text {MT }}$ & KMTTanox $_{\text {MTT. }}$ \\
\hline B-1 & $1.2 \pm 0.03$ & 3.4 & 13.18 \\
B-2 & $0.7 \pm 0.02$ & 3.0 & 6.6 \\
B-3 & $1.0 \pm 0.03$ & 10.8 & 11.5 \\
B-4 & $0.7 \pm 0.02$ & 12.0 & 1.9 \\
B-5 & $0.7 \pm 0.02$ & 29.0 & 21.71 \\
K-1 & $1.8 \pm 0.05$ & 3.5 & 0.6 \\
K-2 & $1.8 \pm 0.05$ & 9.0 & 6.1 \\
\hline
\end{tabular}

Assessment of the respiratory activity was also used in the experiments on the occurring stimulating effect of the products of leaching from the matrix materials and of radiolysis products (Table 7). The addition of electron donors, organic matter (acetate in this case) and hydrogen, resulted in the most pronounced stimulation of respiratory activity in the model of low-mineral groundwater. Similar to the previous experiment, sample B-5 showed the highest respiratory activity. Hydrogen, a product of radiolysis of aqueous solutions, had a greater effect on microbiota development than phosphates and $\mathrm{CO}_{2}$. The addition of the latter resulted in the respiratory activity in samples B-4, B-5, and K-1 increasing two times on average. The addition of a phosphate (which simulated the effect of dissolution of RW-bearing aluminum phosphate glasses in the presence of water) had the greatest effect on the respiration rate-2.5- to 3-fold increase in the samples B-4, B-5, and $\mathrm{K}-1$. Sulfate ions stimulated the respiration of these samples to approximately the same degree. The addition of $\mathrm{CO}_{2}$ had the lowest effect on the respiration rate (the increase was 1.6-fold for sample B-5 and not more than 1.3-fold for other samples). Thus, combined application of organic matter, hydrogen, and biogenic elements: phosphorus resulting from glass leaching and sulfate produced by cement degradation and sulfide oxidation in clays 
and rocks, may result in the most pronounced activation of the microbial complex under DGR-simulating conditions.

Table 7. Stimulation of the respiratory activity of clay microbial complexes by the components of cement and glass barrier degradation and radiolysis products.

\begin{tabular}{cccccc}
\hline Sample & Acetate & $\mathrm{H}_{\mathbf{2}}$ & $\mathbf{P O}_{\mathbf{4}}{ }^{-\mathbf{3}}$ & $\mathbf{S O}_{\mathbf{4}} \mathbf{-}^{\mathbf{2}}$ & $\mathbf{C O}_{\mathbf{2}}$ \\
\hline $\mathrm{B}-1$ & 3.1 & 2.9 & 1.8 & 1.5 & 1.3 \\
$\mathrm{~B}-2$ & 4.3 & 3.1 & 2.3 & 2.5 & 1.4 \\
$\mathrm{~B}-3$ & 2.9 & 2.2 & 1.6 & 1.3 & 1.2 \\
$\mathrm{~B}-4$ & 3.6 & 2.9 & 2.6 & 2.2 & 1.1 \\
$\mathrm{~B}-5$ & 5.5 & 3.9 & 2.9 & 3.1 & 1.6 \\
$\mathrm{~K}-1$ & 4.2 & 2.9 & 2.5 & 2.5 & 1.1 \\
$\mathrm{~K}-2$ & 3.3 & 2.5 & 1.9 & 1.5 & 1.2 \\
\hline
\end{tabular}

\subsection{Clay Elements Leaching by Microbial Complex Stimulation}

Increased concentrations of aluminum and silicon in the aqueous phase are an important indication of the dissolution of the clay mineral structure. The results of analysis of the aqueous phase composition during microbial leaching in the presence of glucose and acetate are presented (as biological leaching coefficients) in Table 8, B-5 and kaolin clays $\mathrm{K}-1, \mathrm{~K}-2$.

Table 8. The coefficients for elements bioleaching from clays after its stimulation with acetate and glucose.

\begin{tabular}{|c|c|c|c|c|c|c|c|}
\hline Sample & K & $\mathrm{Na}$ & $\mathrm{Si}$ & $\mathrm{Ca}$ & Al & $\mathrm{Fe}$ & $\sum$ \\
\hline B-1 & 2.91 & 1.19 & 2.43 & 1.28 & 3.89 & 16.22 & $\overline{27.89}$ \\
\hline B-2 & 1.29 & 1.01 & 0.72 & 0.46 & 2.5 & 0.19 & 6.17 \\
\hline B-3 & 1.38 & 1.02 & 0.71 & 0.65 & 2.63 & 0.37 & 6.65 \\
\hline B-4 & 1.02 & 1 & 1.87 & 0.33 & 2.27 & 2.5 & 8.9 \\
\hline B-5 & 1.92 & 1.04 & 9.21 & 1.89 & 16.73 & 0.87 & 31.66 \\
\hline $\mathrm{K}-1$ & 2.14 & 1.1 & 4.62 & 1.44 & 6.22 & 0.44 & 15.96 \\
\hline $\mathrm{K}-2$ & 3.09 & 1.2 & 2.02 & 0.52 & 6.25 & 0.3 & 12.94 \\
\hline
\end{tabular}

Biological treatment had the strongest effect on the aluminum silicate framework of samples B-5 (by silicon and aluminum) and B1 (by iron). Relatively high release of aluminum and silicon was observed for the kaolin clay samples. The effect of microorganisms on the aluminum silicate framework was the lowest for the samples B-4, B-2 and B-3. Apart from the degradation of the aluminum silicate structural framework, microorganisms may cause iron reduction with its release into the solution. High values of iron leaching were observed for samples B-1 (with high content of iron as a separate mineral phase, ferrihydrite) and B-4. However, not all leached iron is released into the solution; some part of it may be accumulated by the cells and sorbed by microbial biofilms. Potassium release in the presence of microorganisms was the highest for sample B-1 and kaolin clays. The release of this element resulted from the degradation of potassium feldspars and muscovite. Potassium is also accumulated by the cells of developing microbial biofilms. Microbial leaching may result in calcium reprecipitation as calcite due to binding to $\mathrm{CO}_{2}$ produced by the oxidation of organic matter; calcium may also be accumulated in the polysaccharides of microbial biofilms. Thus, the combined effect of microbial processes on bentonite and kaolin clay was revealed, which included the dissolution of the aluminum silicate lattice and leaching of individual ion exchange elements. According to the overall leaching coefficients, microorganisms caused the most pronounced effects in bentonite clays B-1.

\subsection{Biogenic Sulfide Formation}

Sulfide content $(\mathrm{mg} / \mathrm{g})$ in clay materials microbially transformed for one month is shown in Figure 1. Sulfide production depended on the electron donor used and was 
highest in sample B-5. High levels were also found for samples B-4 and K-1 in the presence of acetate. The lowest sulfide content ( 0.2 mg/g clay) was shown for samples B-2 and B-3, while the sulfide level in sample B-1 was below the detection limit. As was reported above, classical sulfate-reducing bacteria have not been detected in microbial complexes of the studied clays by the $16 \mathrm{~S}$ rRNA gene profiling. However, bacilli and other organotrophic bacteria are capable of assimilatory sulfate reduction.

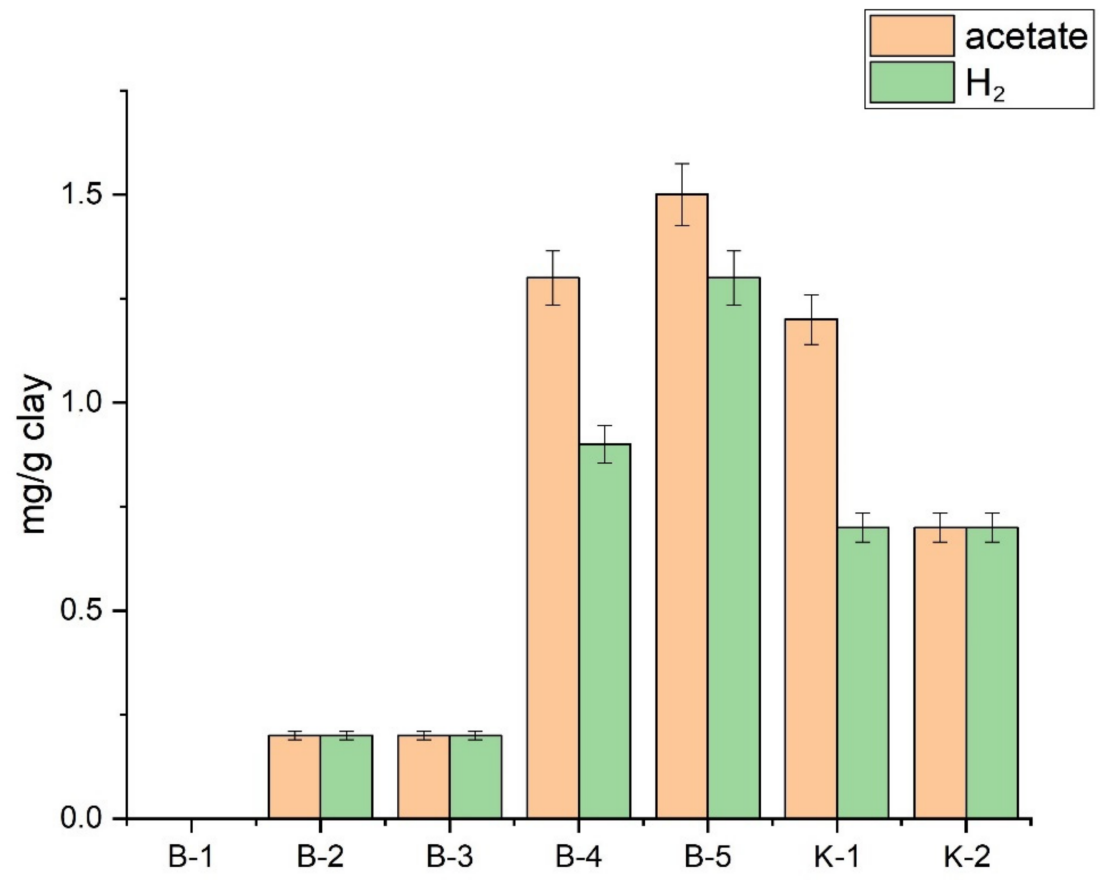

Figure 1. Sulfide content in clay samples after 1-month cultivation with acetate or hydrogen as electron donors.

\section{Discussion}

Thus, it has been established that both the features of the microbial complex of clay materials and their chemical and mineralogical parameters can play an important role in the intensification of microbial processes. We believe that the assessment of the relationship between these parameters can be useful in choosing clay materials for creating safety barriers, since it will allow predicting the likelihood of intensification of microbial processes.

\subsection{Correlations between the Composition of Clay Materials and Microbial Processes}

The correlation between the clay elemental composition and the rates of microbial processes was assessed using the Spearman rank correlation coefficient (Figure 2). A high direct correlation was observed between microbial respiratory activity and contents of phosphorus, nitrogen, and carbon in clay samples, while the correlation with iron content was relatively weak. Sulfide production also correlated strongly with the levels of C, N, and $\mathrm{P}$, while its correlation with iron content was inverse. This was probably the result of competition between the processes of sulfur and iron reduction, as was the case with sample B-1 containing over 10 mass \% iron. Dissolution of the aluminum silicate structure determined by aluminum and silicon leaching into the solution also exhibited a strong direct correlation with the content of $\mathrm{C}, \mathrm{N}$, and P in the samples and the strongest direct correlation with iron. Potassium release inversely correlated with the levels of iron and sulfur, while iron release showed a weak positive correlation with iron and sulfur content and a weak negative one with the levels of $C, N$, and $P$. The absence of clear correlations may be explained by decreased release of these elements into the solution due to their accumulation in microbial biofilms on clay. 


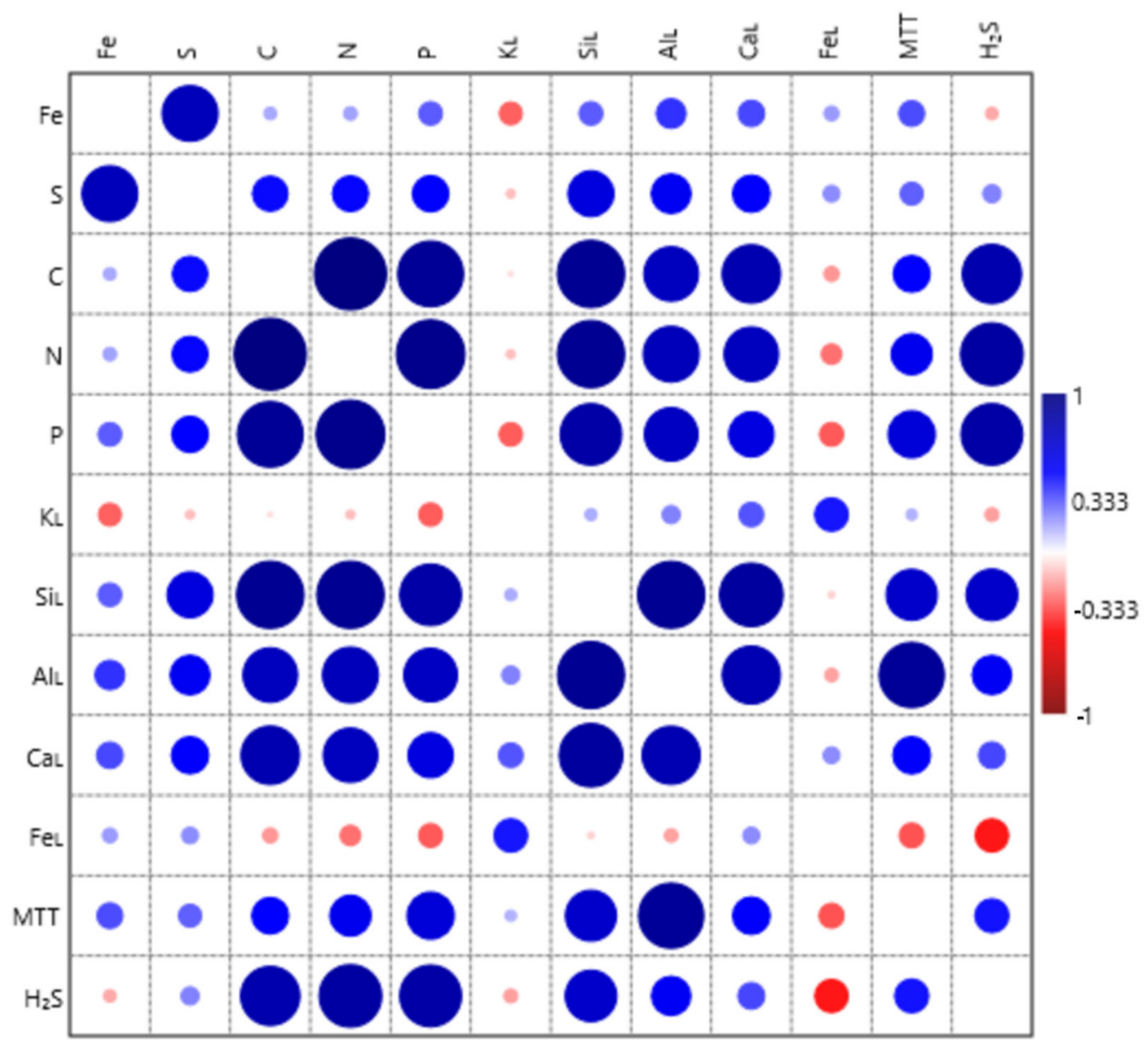

Figure 2. Relations between elemental composition and microbial processes in clay materials. "L" after the symbol of an element indicates bioleaching.

Assessment of the strength of correlational relationships between the clay minerals composition and the rates of microbial processes is presented in Figure 3. Strong direct correlations $(p<0.05)$ between the respiratory activity and kaolinite and potassium feldspar levels should be noted. The PFS is the most weathering-susceptible mineral, which acts as a potassium source for the cells. Similar to other clay minerals, microbial growth on kaolinite may be initiated by iron. The data on microbial conversion of kaolinite to illite due to $\mathrm{Fe}, \mathrm{Si}$, and $\mathrm{Mg}$ absorption and subsequent iron reduction with the absorption of potassium and ammonium ions are presented in the review by G.L. Li [15]. This work also describes the microbial conversion of illite to smectite. Microbial growth in the presence of illite in various polymineral samples was due to the high content of potassium and iron. A relatively strong correlation was also found between microbial respiration and illite content. Interestingly, a strong inverse correlation was revealed between microbial respiration and montmorillonite content. This may be explained by pronounced swelling of montmorillonite and morphological limitations for biofilm formation. At the same time, a strong positive correlation between microbial respiration and the content of quartz, which contains no biophilic elements, may be explained by the same factor, i.e., the possibility of biofilm formation on its large grains. 


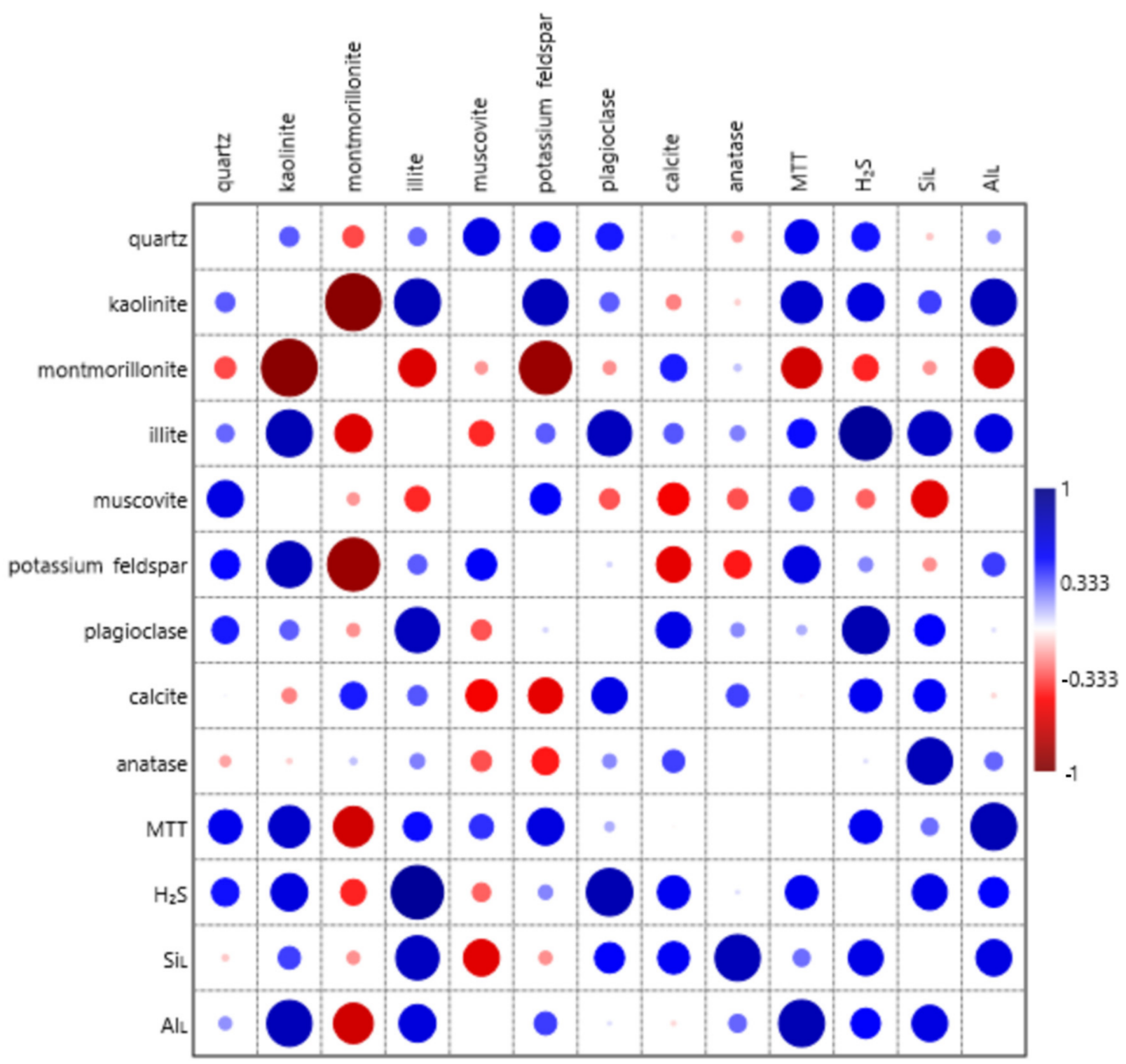

Figure 3. Relations between mineral composition and the processes in clays.

Sulfide production exhibited a strong positive correlation with the levels of illite, plagioclase, calcite, and kaolinite. A negative correlation was also found for montmorillonite content, although, in contrast the case of microbial respiration, its reliability was low.

The degradation of the aluminum silicate lattice of clay materials correlated directly with the contents of kaolinite, illite, calcite, anatase, and PFS in the samples. Similar to other microbial processes, a strong inverse correlation with montmorillonite content was observed.

\subsection{Calculation of Overall Safety for Clay Materials}

The procedure for prediction of the overall safety of clay materials was proposed based on the results of analysis of the data obtained at all experimental stages (Table 9). Ranking the parameters according to their estimated value (from 1 to 5) showed that the B-5 clay sample (Zyryanskoye bentonite) exhibited the highest biological hazard and in our opinion is unsuitable for application in engineered barriers. The clays B-2, B-3, and B-4 (Dinozavrov, Kamalinsk, and 10th Khutor bentonite deposits, respectively) proved 
the most suitable for the application. The clay B-1 (Kutch) and kaolin clays K-1 and K-2 showed relatively high biohazard values and may be used with limitations, e.g., with the compulsory introduction of biocidal additives, or only in a compressed form.

Table 9. Overall safety prediction for clay materials.

\begin{tabular}{|c|c|c|c|c|c|c|c|c|}
\hline Parameters & & B-1 & B-2 & B-3 & B-4 & B-5 & $\mathrm{K}-\mathbf{1}$ & K-2 \\
\hline \multirow{5}{*}{$\begin{array}{l}\text { Biogenic elements } \\
\text { in clays }\end{array}$} & $\mathrm{Fe}$ & 4 & 4 & 4 & 2 & 5 & 1 & 1 \\
\hline & $S$ & 3 & 3 & 1 & 2 & 5 & 1 & 1 \\
\hline & $\mathrm{C}$ & 2 & 3 & 1 & 2 & 5 & 4 & 1 \\
\hline & $\mathrm{N}$ & 1 & 1 & 1 & 1 & 3 & 2 & 1 \\
\hline & $\mathrm{P}$ & 1 & 1 & 1 & 2 & 4 & 2 & 1 \\
\hline \multicolumn{2}{|c|}{ Acid leachate $\sum$} & 5 & 3 & 3 & 3 & 4 & 3 & 1 \\
\hline \multirow{6}{*}{ Bioleachates } & $\mathrm{K}_{\mathrm{L}}$ & 5 & 1 & 2 & 1 & 3 & 3 & 5 \\
\hline & SiL & 3 & 1 & 1 & 2 & 5 & 3 & 2 \\
\hline & $\mathrm{AlL}$ & 2 & 1 & 1 & 1 & 5 & 3 & 3 \\
\hline & $\mathrm{CaL}$ & 3 & 1 & 2 & 1 & 5 & 4 & 1 \\
\hline & $\mathrm{FeL}_{\mathrm{L}}$ & 5 & 1 & 1 & 2 & 1 & 1 & 1 \\
\hline & $\mathrm{NaL}$ & 2 & 1 & 4 & 1 & 2 & 5 & 4 \\
\hline \multicolumn{2}{|c|}{ MTTinit } & 3 & 1 & 2 & 1 & 1 & 5 & 5 \\
\hline \multicolumn{2}{|c|}{ MTTox } & 1 & 1 & 3 & 1 & 5 & 2 & 3 \\
\hline \multicolumn{2}{|c|}{ MTTanox } & 2 & 2 & 5 & 1 & 5 & 1 & 5 \\
\hline \multicolumn{2}{|c|}{$\mathrm{H}_{2} \mathrm{~S}$} & 1 & 1 & 1 & 3 & 5 & 3 & 2 \\
\hline \multicolumn{2}{|c|}{ Total } & 43 & 26 & 33 & 26 & 63 & 43 & 37 \\
\hline
\end{tabular}

\section{Conclusions}

The clays used in DGR as safety barriers were found to be able to act as sources of microflora and biogenic elements, which may have a negative effect on the DGR safety. The clay microbial complex contained primarily aerobic and anaerobic organotrophic bacteria due to secondary contamination at the plants. Microbial processes in clay barriers may be stimulated by the clay's organic matter, hydrogen of radiolytic origin, and release of biogenic elements (iron, potassium, sulfur, phosphorus, etc.) from the barriers. Microbial processes occurring in clay materials result in their partial dissolution and release of cations into the solution, impairing their sorption properties and favoring liquid diffusion. Formation of biogenic gases, including hydrogen sulfide, was observed in activated microbial complexes from the samples with high content of sulfur and organic carbon (bentonite from Zyryanskoye deposit); it may result in corrosion of steel RW containers. A positive correlation of the rates of microbial processes was found with the levels of sulfur, phosphorus, and iron in clays; both the elemental and mineral composition of the samples, as well as with their morphological properties, affected the development of microbial processes. An approach to ranking the bentonite and kaolin clay materials according to the safety of their application in engineered barriers was proposed based on a combination of factors.

Supplementary Materials: The following supporting information can be downloaded at: https: / / www.mdpi.com/article/10.3390/app12041843/s1, Table S1: title Experimental design and measurements techniques description.

Author Contributions: Conceptualization, E.Z. and A.S.; methodology, A.S.; validation, E.A., N.P. and G.A.; formal analysis, V.Z.; investigation, E.A., N.P., G.A. and V.Z.; writing-original draft preparation, A.S., E.A. and N.P.; writing-review and editing, A.S., E.A. and N.P.; visualization, N.P. and E.A.; supervision, A.S. All authors have read and agreed to the published version of the manuscript.

Funding: This work was supported by state assignments from The Ministry of Science and Higher Education of the Russian Federation (\#AAAA-A16-11611091001).

Institutional Review Board Statement: Not applicable.

Informed Consent Statement: Not applicable. 
Data Availability Statement: Data is contained within the article.

Acknowledgments: This work was performed using the equipment of the Core Facilities Center of IPCE RAS (CKP FMI IPCE RAS).

Conflicts of Interest: The authors declare no conflict of interest.

\section{References}

1. Delage, P.; Cui, Y.J.; Tang, A.M. Clays in radioactive waste disposal. J. Rock Mech. Geotech. Eng. 2010, 2, 111-123. [CrossRef]

2. Dohrmanna, R.; Kaufhold, S.; Lundqvist, B. The Role of Clays for Safe Storage of Nuclear Waste. In Handbook of Clay Science, 2nd ed.; Bergaya, F., Lagaly, G., Eds.; Elsevier: Amsterdam, The Netherlands, 2013; Volume 5, pp. 677-710. [CrossRef]

3. Pedersen, K. Microbial Processes in Radioactive Waste Disposal; SKB TR-00-04; Swedish Nuclear Fuel and Waste Management Co.: Stockholm, Sweden, 2000; 92p.

4. Mijnendonckx, K.; Honty, M.; Wang, L.; Jacops, E.; Provoost, A.; Mysara, M.; Wouters, K.; De Craen, M.; Leys, N. An active microbial community in Boom Clay pore water collected from piezometers impedes validating predictive modelling of ongoing geochemical processes. J. Appl. Geochem. 2019, 106, 149-160. [CrossRef]

5. $\quad$ Äspö Hard Rock Laboratory. Annual Report 2016; SKB TR-17-10; Swedish Nuclear Fuel and Waste Management Co.: Solna, Sweden, 2016; 130p.

6. Leupin, O.X.; Bernier-Latmani, R.; Bagnoud, A.; Moors, H.; Leys, N.; Wouters, K.; Stroes-Gascoyne, S. Fifteen years of microbiological investigation in Opalinus Clay at the Mont Terri rock laboratory (Switzerland). Swiss J. Geosci. 2017, 110, $343-354$. [CrossRef]

7. Meleshyn, A.Y.; Zakusin, S.V.; Krupskaya, V.V. Swelling Pressure and Permeability of Compacted Bentonite from 10th Khutor Deposit (Russia). Minerals 2021, 11, 742. [CrossRef]

8. Belousov, P.; Chupalenkov, N.; Christidis, G.E.; Zakusina, O.; Zakusin, S.; Morozov, I.; Chernov, M.; Zaitseva, T.; Tyupina, E.; Krupskaya, V. Carboniferous bentonites from 10Th Khutor deposit (Russia): Composition, properties and features of genesis. Appl. Clay Sci. 2021, 215, 106308. [CrossRef]

9. Characterization of Swelling Clays as Components of the Engineered Barriers System for Geological Repositories; IAEA-TECDOC-1718; IAEA: Vienna, Austria, 2013; 102p, Available online: https:/ /www.iaea.org/publications /8525/characterization-of-swellingclays-as-components-of-the-engineered-barrier-system-for-geological-repositories (accessed on 29 November 2021).

10. Ilina, O.A.; Krupskaya, V.V.; Vinokurov, S.E.; Kalmykov, S.N. State-of-Art in the Development and Use of Clay Materials as Engineered Safety Barriers at Radioactive Waste Conservation and Disposal Facilities in Russia. Radioact. Waste 2019, 4, 71-84. [CrossRef]

11. Martynov, K.V.; Zakharova, E.V.; Dorofeev, A.N.; Zubkov, A.A.; Prishchep, A.A. Use of Clay Materials in the Construction of Protective Barriers at Radiation Hazardous Facilities. Radioact. Waste 2020, 3, 39-53. (In Russian) [CrossRef]

12. Stoulil, J.; Kaňok, J.; Kouřil, M.; Parschová, H.; Novák, P. Influence of temperature on corrosion rate and porosity of corrosion products of carbon steel in anoxic bentonite environment. J. Nucl. Mater. 2013, 443, 20-25. [CrossRef]

13. Schwartz, M.O. Corrosion-Enhancing and Corrosion-Reducing Accessories in Bentonite Surrounding Copper-Shielded Containers for Nuclear Waste. J Hazard Toxic Radioact. Waste 2021, 25, 04021024. [CrossRef]

14. Cuadros, J. Clay minerals interaction with microorganisms: A review. Clay Miner. 2017, 52, 235-261. [CrossRef]

15. Li, G.L.; Zhou, C.H.; Fiore, S.; Yu, W.H. Interactions between microorganisms and clay minerals: New insights and broader applications. Appl. Clay Sci. 2019, 177, 91-113. [CrossRef]

16. Naĭmark, E.B.; Eroshchev-Shak, V.A.; Chizhikova, N.P.; Kompantseva, E.I. Interaction of clay minerals with microorganisms: A review of experimental data. Zhurnal Obs. Biol. 2009, 70, 155-167.

17. Dong, H.; Jaisi, D.P.; Kim, J.; Zhang, G. Microbe-clay mineral interactions. Am. Mineral. 2009, 94, 1505-1519. [CrossRef]

18. Hong, H.; Fang, Q.; Cheng, L.; Wang, C.; Churchman, G.J. Microorganism-induced weathering of clay minerals in a hydromorphic soil. Geochim. Cosmochim. Acta 2016, 184, 272-288. [CrossRef]

19. Fang, Q.; Churchman, G.J.; Hong, H.; Chen, Z.Q.; Liu, J.; Yu, J.; Han, W.; Wang, C.; Zhao, L.; Furnes, H. New insights into microbial smectite illitization in the Permo-Triassic boundary K-bentonites, South China. Appl. Clay Sci. 2017, 140, 96-111. [CrossRef]

20. Huggett, J.M.; Cuadros, J. Low-temperature illitization of smectite in the late eocene and early oligocene of the Isle of Wight (Hampshire basin), U.K. Am. Mineral. 2005, 90, 1192-1202. [CrossRef]

21. Wouters, K.; Moors, H.; Boven, P.; Leys, N. Evidence and characteristics of a diverse and metabolically active microbial community in deep subsurface clay borehole water. FEMS Microbiol. Ecol. 2013, 86, 458-473. [CrossRef] [PubMed]

22. Gregory, S.P.; Barnett, M.J.; Field, L.P.; Milodowski, A.E. Subsurface Microbial Hydrogen Cycling: Natural Occurrence and Implications for Industry. Microorganisms 2019, 7, 53. [CrossRef]

23. Wilson, J. FEBEX-DP: Geochemical Modelling of Iron-Bentonite Interactions; Quintessa's Contribution on Behalf of RWM QRS-1713AR3, 1.3.; Quintessa Limited: Oxford, UK, 2017; p. 68.

24. Bengtsson, A.; Blom, A.; Hallbeck, B.; Heed, C.; Johansson, L.; Stahlén, J.; Pedersen, K. Microbial Sulphide-Producing Activity in Water Saturated MX80, Asha and Calcigel Bentonite at Wet Densities from 1500 to $2000 \mathrm{~kg} \mathrm{~m}^{-3}$; SKB Report TR 16-09; Swedish Nuclear Fuel and Waste Management Co.: Stockholm, Sweden, 2016; pp. 1-50. 
25. Pedersen, K. Analysis of copper corrosion in compacted bentonite clay as a function of clay density and growth conditions for sulfate-reducing bacteria. J. Appl. Microbiol. 2010, 108, 1094-1104. [CrossRef]

26. Chi, F.E.; Athar, R. In situ bacterial colonization of compacted bentonite under deep geological high-level radioactive waste repository conditions. Appl. Microbiol. Biotechnol. 2008, 79, 499-510. [CrossRef]

27. Mirgorodskaya, A.B.; Lukashenko, S.S.; Kudryavtsev, D.B.; Zakharova, L.Y.; Panteleeva, A.R.; Konovalov, A.I.; Jatskevich, E.I. Corrosion Inhibitor-Bactericide for Mineralized Hydrogen Sulfide and Carbon Dioxide Environments. RU 2503746 C1, 10 January 2014.

28. Domb, A.J.; Brzezinska, M.S.; Walczak, M.; Jankiewicz, U.; Pejchalová, M. Antimicrobial Activity of Polyhexamethylene Guanidine Derivatives Introduced into Polycaprolactone. J. Polym. Environ. 2018, 26, 589-595. [CrossRef]

29. Kamorny, D.A.; Safonov, A.V.; Boldyrev, K.A.; Abramova, E.S.; Tyupina, E.A.; Gorbunova, O.A. Modification of the Cement Matrix with Organic Additives for Stabilizing Pertechnetate Ions. J. Nucl. Mater. 2021, 557, 153295. [CrossRef]

30. Varlakov, A.P.; Gorbunova, O.A.; Barinov, A.S.; Iljin, V.A.; Efimov, K.M.; Gembitsky, P.A. Application of Polyhexamethyleneguanidine Type Biocides at Cementing the Radioactive Waste. In Proceedings of the ASME 2001 8th International Conference on Radioactive Waste Management and Environmental Remediation, Bruges, Belgium, 30 September-4 October 2001; pp. 701-703.

31. Gribi, P.; Johnson, L.; Marschall, P.; Wersin, P. Safety Assessment for a KBS-3H Spent Nuclear Fuel Repository at OLKILUOTO; Process Report. SKB Rapport R-08-36; Swedish Nuclear Fuel and Waste Management Co.: Solna, Sweden, 2008; p. 320.

32. Abramova, E.S.; Artemyev, G.D.; Popova, N.M.; Safonov, A.V. Microbial Processes in Engineering Clay Materials and Biocidal Additives to Prevent Them. Biotechnology 2021, 37, 65-74. [CrossRef]

33. Olsson, S.; Karnland, O. Characterisation of Bentonites from Kutch, India and Milos, Greece-Some Candidate Tunnel Back-Fill Materials? Clay Technology AB, SKB Rapport R-09-53. Available online: https://skb.se/upload/publications/pdf/R-09-53.pdf (accessed on 29 November 2021).

34. Krupskaya, V.V.; Biryukov, D.V.; Belousov, P.E.; Lekhov, V.A.; Romanchuk, A.Y.; Kalmykov, S.N. The use of natural clay materials to increase the nuclear and radiation safety level of nuclear legacy facilities. Radioact. Waste 2018, 2, 30-43.

35. Belousov, P.E.; Krupskaya, V.V. Bentonite clays of Russia and neighboring countries. Georesursy Georesources 2019, 21, 79-90. [CrossRef]

36. Patel, P.K. Lateritization and bentonitization of basalt in Kutch, Gujarat State, India. Sediment. Geol. 1987, 53, 327-346. [CrossRef]

37. Laverov, N.P.; Yudintsev, S.V.; Kochkin, B.T.; Malkovsky, V.I. The Russian Strategy of using Crystalline Rock as a Repository for Nuclear Waste. Elements 2016, 12, 253-256. [CrossRef]

38. Rozov, K.B.; Rumynin, V.G.; Nikulenkov, A.M.; Leskova, P.G. Sorption of 137Cs, 90Sr, Se, 99Tc, 152(154)Eu, 239(240)Pu on fractured rocks of the Yeniseysky site (Nizhne-Kansky massif, Krasnoyarsk region, Russia). J. Environ. Radioact. 2018, 192, 513-523. [CrossRef] [PubMed]

39. Cory, A.H.; Owen, T.C.; Barltrop, J.A.; Cory, J.G. Use of an aqueous soluble tetrazolium/formazan assay for cell growth assays in culture. Cancer Commun. 1991, 3, 207-212. [CrossRef] [PubMed]

40. Trüper, H.G.; Schlegel, H.G. Sulphur metabolism in Thiorhodaceae I. Quantitative measurements on growing cells of Chromatium okenii. Antonie Leeuwenhoek 1964, 30, 225-238. [CrossRef] [PubMed]

41. Dong, H. Clay-Microbe Interactions and Implications for Environmental Mitigation. Elements 2012, 8, 113-118. [CrossRef]

42. Nishiyama, T.; Ueki, A.; Kaku, N.; Watanabe, K.; Ueki, K. Bacteroides graminisolvens sp. nov., a xylanolytic anaerobe isolated from a methanogenic reactor treating cattle waste. Int. J. Syst. Evol. 2009, 59, 1901-1907. [CrossRef] [PubMed]

43. Tapio, I.; Snelling, T.J.; Strozzi, F.; Wallace, R.J. The ruminal microbiome associated with methane emissions from ruminant livestock. J. Anim. Sci. Biotechnol. 2017, 8, 7. [CrossRef] [PubMed]

44. Janssen, P.H.; Hugenholtz, P. Fermentation of glycolate by a pure culture of a strictly anaerobic gram-positive bacterium belonging to the family Lachnospiraceae. Arch. Microbiol. 2003, 179, 321-328. [CrossRef]

45. Abhishek, G.; Avishek, D.; Jayeeta, S.; Panigrahi, M.K.; Sar, P. Low-Abundance Members of the Firmicutes Facilitate Bioremediation of Soil Impacted by Highly Acidic Mine Drainage From the Malanjkhand Copper Project, India. Front. Microbiol. 2019, 9, 2882. [CrossRef]

46. Cai, M.H.; Luo, G.; Li, J.; Li, W.T.; Li, Y.; Li, A.M. Substrate competition and microbial function in sulfate-reducing internal circulation anaerobic reactor in the presence of nitrate. Chemosphere 2021, 280, 130937. [CrossRef]

47. Wang, H.; Zhu, Y.; Hu, C. Impacts of bacteria and corrosion on removal of natural organic matter and disinfection byproducts in different drinking water distribution systems. Int. Biodeterior. Biodegrad. 2017, 117, 52-59. [CrossRef]

48. Singh, P.B.; Saini, H.S.; Kahlon, R.S. Pseudomonas: The versatile and adaptive metabolic network. In Pseudomonas: Molecular and Applied Biology, 1st ed.; Kahlon, S., Ed.; Springer: Berlin/Heidelberg, Germany, 2016; Volume 1, pp. 81-126. [CrossRef]

49. Wood, T.L.; Gong, T.; Zhu, L.; Miller, J.; Miller, D.S.; Yin, B.; Wood, T.K. Rhamnolipids from Pseudomonas aeruginosa disperse the biofilms of sulfate-reducing bacteria. npj Biofilms Microbiomes 2018, 4, 22. [CrossRef] [PubMed]

50. Abdelouas, A.; Grambow, B.; Fattahi, M.; Andres, Y.; Leclerc-Cessac, E. Microbial reduction of 99Tc in organic matter-rich soils. Sci. Total Environ. 2005, 336, 255-268. [CrossRef] 